DOI https://doi.org/10.30525/978-9934-588-91-4-41

\title{
ОБЕСПЕЧЕНИЕ НАЦИОНАЛЬНЫХ ИНТЕРЕСОВ ПРИ ПОСТГЛОБАЛЬНОМ ИЗМЕНЕНИИ ФОРМАТА МЕЖДУНАРОДНОГО МИРОУСТРОЙСТВА
}

\author{
Шедяков В. Е. \\ доктор социологических наук, \\ независимый исследователь \\ г. Киев, Украина
}

Постглобальные трансформации парадигмального уровня, Всесторонний учёт характера воздействия на состояние и динамику национальной безопасности, на процессы, влияющие на интересы страны один из приоритетных элементов успешного осуществления модернизации экономики и финансовой системы. Сохраняя достигнутый уровень обобществления международной жизни, ойкумена упёрлась в препятствие своим безопасности и развитию, связанное с сохранением устаревшей организации миропорядка, обслуживаемой идеями то вульгарного мультикультурализма, то примитивного национального эгоизма [1-3]. Переструктурирование обогащается конкретными характеристиками чернового наброска будущего, создания его замысла и выявления намерения, наиболее обостренно проявляясь именно в переходный период. Очередной парадигмальный скачок в развитии ойкумены объективно требует соответствующих изменений стратегий защиты национальных интересов. Их коренная модернизация тем насущней, что осуществляется переход к принципиальной многополюсности и признанию права на разнообразие. Важнейшими субъектами поиска и культивирования новых моделей общежития (как и защиты населения) проявили себя отнюдь не транснациональные корпорации или международные организации, а именно государства. Разумеется, трансформации внутреннего и внешнего политико-экономического порядка взаиморезонируют. При этом современные научные подходы вынуждены принимать во внимание то обстоятельство, что международные экономические отношения становятся всеобъемлющими при распространении на все стороны воспроизводства, в частности, не только на распределение и обмен, но и на производство.

Периодические трансформации парадигмального качества - неизбежность развития как, в частности, «повивальная бабка истории». Но сам период форсированных изменений, очевидно, - это не время приращения на установившейся основе, вовсе не эпоха процветания, а эра кризиса и выхода на поверхность накопленных противоречий, 
поляризации общества и обострения борьбы. Сумеют ли выполнить свою генерализующую функцию потенциальные «локомотивы» во многом определяется взаимоотношением народа и элиты. Социальноэкономическая готовность стран и народов к новым условиям должна получить адекватное отражение во внутреннем и внешнем курсе. При этом сущность взаимоподдержки друг друга традициями и инновациями - в политико-экономическом и социокультурном устройстве порядка жизни (внутреннего и международного), который, чтобы быть созидательным, должен восприниматься народом как справедливый, должный. Для этого, в свою очередь, не должно существовать привилегий для власть имущих и агрессивных меньшинств, прикрываемых лживыми лозунгами и т.д. [4; 5].

Так, как известно, послевоенный миропорядок основывался на ялтинско-потсдамско-хельсинкских договорённостях и, во многом, подпитывался социальными завоеваниями социализма, а также необходимостью для капиталистического лагеря заботится о своей привлекательности в условиях соревнования мировых систем. Ликвидация государственных образований ГДР, СССР, СФРЮ, а также мировой системы социализма, ОВД и СЭВ ознаменовала разрушение существовавшего миропорядка. Конструкция с монополией на мировое господство западных кланов во главе с США не могла быть устойчивой и оказалась исторически мимолётным балансированием. Очевидно: ойкумена меняется крайне быстро; «стрела истории» летит всё быстрее. Причём Запад во многом сохраняет пока инструменты поддержания могущества, но утратил привлекательность. Возникают новый геостратегический порядок, новые модели развития, которые ищутся в диапазоне от восстановления архаики империй и неокастовости общества до радикального усиления народовластия, самоуправления, суверенитета.

Наступление постглобальной эпохи отражается в комплексном характере перемен: как постглобальности объективного состояния, так и постглобализма осознания происходящего. С одной стороны, мироустройство зиждилось на международном разделении труда и мировых потоках капитала, товаров и услуг, в частности - глобализации информации и, соответственно, представлений о стандартах уровня жизни, в т.ч. образования, здравоохранения и т.д. Многие из появившихся примет наднационального взаимодействия необратимы. Воспроизводство ойкумены накрепко связало культурно-цивилизационные миры, формой чего и стало соотношение конкурентности / состязательности и партнерства / кооперации с той или иной степенью комплиментарности или же, напротив, враждебности. С другой стороны, нарастает понимание ценности своей идентичности и прямой зависимости качества социально-экономического 
роста от реальности суверенитета и качества социализации [6-8]. Между тем, новая эпоха резко повышает вероятность новых волн массовых угроз. Причём детерминанты патогенности вариативны и комбинируемы, что расширяет перспективы направленной селекции определённых признаков. Мировые трансформации ещё раз демонстрируют: у каждого из субъектов истории своя комбинация преимуществ и недостатков. Их осознание и учёт - важнейший элемент создания эффективного Сверхпроекта развития и уяснения путей гармонии человека и общества в стратегии, тактике и оператике модернизации.

Разумеется, сам процесс преобразований может происходить с большими или меньшими эксцессами. Сегодня тенденции к регионализации, к борьбе за глобальное лидерство и к повышению подконтрольности личности на основе цифровизации-чипизации взаимодействуют и накладываются друг на друга. Стратегически важно, чтобы трансформации не стали отказом от наработок и достижений прошлого, а укрепили и расширили ресурсно-методологическую базу жизнедеятельности и развития каждого именно при интеграции созидательных потенциалов, в том числе, и отечественных моделей как модерна, так и традиции. Органичность сочетания преемственности и развития важнейшее условие защиты идентичности постсоветского пространства, что высвечивает роль и лидеров, и институтов. Крайне существенно, чтобы поле социального и индивидуального творчества возрастало, а качество и длительность жизни - увеличивались. Обществу: как отдельного культурно-цивилизационного мира, так и ойкумены - важно разнообразие мировоззрений, поисков, подходов, покуда оно не подрывает основ его существования. Плодотворная защита исторической памяти при понимании всемирно-исторического процесса как непрерывного и постоянного требует учить население размышлять, действовать, творить: самостоятельно и в коллективе.

\section{Литература:}

1. Валлерстайн И. Геополитические миро-системные изменения: 1945-2025 годы. Bonросы экономики. 2006. № 4. С. 67-82.

2. Геєць В. М. Конфігурація геополітичної карти світу та їі проблемність. Економіка Украӥни. 2011. № 1. С. 4-15.

3. Шедяков В. Е Самоуправление и народовластие: хозяйственные механизмы возрождения. Экономика, общество, рынок: научные записки. Харьков: Изд-во ХИУ, 1998. Вып. 4. С. 123-155.

4. Шедяков В. Е. Укрепление внешнего контура народовластия условие эффективного участия в международной жизни. Politicus. 2019. Вип. 5. С. 81-87. DOI https://doi.org/10.24195/2414-9616-2019-5-81-87

5. Шедяков В. Е. Обеспечение экономического суверенитета: глобализм и регионализм в социально-экономических отношениях. 
Economy and Management: Modern Transformation in the Age of Globalization: Proceed. of II Intern. Scient. Conf. Klaipeda, March 23 ${ }^{\text {th }}$, 2018. P. 68.

6. Шедяков В. Е. Постглобальные возможности и угрозы: диапазон решений. Economic Development: Global Trends and National Peculiarities / ed. by A. Pawlik, K. Shaposhnykov. Kielce: Baltija Publishing, 2020. P. 261-275. DOI: 10.30525/978-9934-588-61-7-18

7. Шедяков В. Е. Развитие международных экономических отношений в эпоху постглобализма. Innovative Potential of Socio-Economic Systems: the Challenges of the Global World: Proceed. of III Intern. Scient. Conf. Lisbon, December $28^{\text {th }}, 2018$. P. 11-13.

8. Шедяков В. Е. Межпарадигмальный переход в структуре и организации международной жизни. Research, challenges and development prospects in the area of social sciences / ed. board: J. Kloc, U. Kempińska, Z. Brenda; Cuiavian University in Wloclawek. Riga: Baltija Publishing, 2020. P. 301-325. DOI https://doi.org/10.36059/9789934-588-42-6/301-325 